J. Management and Humanity Research Vol. 2, 2020, 19-28

ISSN: 2582-7766 (online)

Published on 25 January 2020

www.researchmathsci.org

DOI: http://dx.doi.org/10.22457/jmhr.v02a03203

Journal of

Management and

Humanity Research

\title{
Determinants of China Foreign Direct Investment (FDI's) in Bangladesh from the Perspective of Economic Development
}

\author{
Dulal Roy" \\ School of Economics and Management \\ University of Dhaka, Dhaka - 1212, Dhaka, \\ Bangladesh. Email: liwei-cqu@ hotmail.com \\ Received 6 December 2019; accepted 15 January 2020
}

\begin{abstract}
The purpose of this paper is to assess customer satisfaction in the banking sector in Bangladesh. The paper uses empirical research methods to collect the main data needed through a well-structured questionnaire. The validity and reliability of the questionnaire items were tested with SPSS software. The results show that when independently examining the impact of service quality, service cost and perceived value on customer satisfaction, these three variables have a significant impact on the two types of customer satisfaction. However, when conducting joint tests, only the perceived value still has a significant impact on the satisfaction of the financial transaction business and other comprehensive service satisfaction, and the influence of the other two independent variables is no longer significant. The above phenomenon shows that consumers' perceived value of services has a greater impact on their satisfaction than service quality and service costs.
\end{abstract}

Keywords: service quality, service cost, perceived value, customer satisfaction

\section{Introduction}

The Government of Bangladesh recognizes the private sector is an essential engine of development and welcomes Foreign Direct Investment (FDI). Furthermore, Bangladesh government pays special attention to attract FDI from China. This research work intended to determinants China FDI from the Bangladesh of perspective economics development. Foreign direct investment is usually considered a major source of growth (Islam, 2017). FDI is an important source of finance for transition economics, as it helps to cover the current account deficit and fiscal deficit and supplements inadequate domestic's resources to finance both ownership change and capital formation (Trade and Development 2008) 
found that FDI was important to the Bangladesh economy because it brought investable financial resources provided new technology and enhance the efficiency of existing technologies.

The aim of this research to investigate the determinants of China foreign direct investment in Bangladesh from the prospective of economic development. The purpose is to have the broad understanding of determinants of China foreign direct investment (FDI's) in Bangladesh from the perspective in economic development. If it has positive or negative impacts to the Bangladesh economy (Long et al, 2015). The aim of this thesis is to empirically examine the determinants of FDI derived from the problem statement and rooted in the literature. The fact that the research questions are derived from literature and are connected to the thesis analysis and discussion parts is important in order to develop a logical thread that can be easily followed. What are the determinants of China Foreign Direct Investment (FDI's) in Bangladesh from the perspective of economic development. What are the determinants of China FDI in Bangladesh perspective economic development? What are the contributions of China FDI in economic development in Bangladesh?

\section{Literature review}

Foreign direct investment (FDI) is an investment in a business by an investor from another country for which the foreign investor has control over the company purchased (Ahmed,2018). The Organization of Economic Cooperation and Development (OECD) defines control as owning $10 \%$ or more of the business. Businesses that make foreign direct investments are often called multinational corporations (MNCs) or multinational enterprises (MNEs). An MNE may make a direct investment by creating a new foreign enterprise, which is called a Greenfield investment, or by the acquisition of a foreign firm, either called an acquisition or brownfield investment. FDI has been increasing since the beginning of globalization (Hirst), Thompson et all (2005) due to among others improved education systems and the better understanding of global markets (Kolawole, 2015)8 . technical development the establishment of trade union and common markets, the facilitation of the global movement of goods through commonly accepted trade lows and international treaties as well as the integration of several countries domestic. According to Raihan et al. (Raihan, 2015), financial globalization is the increase of foreign capital movement among several countries of the world. In developing markets, financial globalization is mainly promoted by the relatively high return on capital investment compared to developed countries and the availability of rather inexpensive human resource.

One of the older theories in FDI literature is capital movement theory. The capital movement theory states (Roy, 2017) that is mainly determined by interest rate. Dunning 


\section{Determinants of China Foreign Direct Investment (FDI's) in Bangladesh from the}

Perspective of Economic Development

argue that the prevailing explanation of international capital movement relied exclusively up on a neoclassical financial theory of portfolio. An important FDI theory based on macro-economic influence state that some investor make their decisions to inter a foreign market based on exchange rate consideration (Sharmin, 2015). Sungand Lapan argue that exchange rate uncertainty between a company's home country and foreign target sometime encourages a firm to open a foreign subsidiary in order to be able to have more control over a relatively volatile exchange rate by producing and market the products for a particular target market domestically (Islam, 2017).

Feldmann has evaluated the contribution of FDI to domestic productivity and found positive impacts of FDI on economic development (Feldmann, 2017). Again, Levine et al. found negative results on economic development. Kumar, Sushil, and Shahid Ahmed found an immediate troublesome effect of FDI flows on developing countries (Kumar, 2014). This effect would overcome after a short period of time, with positive impacts on growth. Long, Yang and Zhang (Long et al, 2015) used his model to explore the impact of foreign investment on the growth of Bangladesh and found that FDI has a positive impact on growth. He also found a strong positive effect of the change in the level of domestic investment on growth. V.N.Balasubramanyam, Mitra, Sandip did an examination about the impact of FDI on economic growth in developing economies using ordinary least squares (Mitra, 2015). Applying the export promotion strategy, they found positive and significant impact of FDI on economic growth in developing countries. Simultaneously, it also showed that such relations do not exist in developing countries applying the import substitution strategy. Bengoa and Sanchez-Robles showed the positive correlation between FDI and economic growth. In this connection, with a view to getting benefit from long term FDI inflows, human capital, stable economic condition and liberalized markets are required in host countries. Blanchard et al examined the data on FDI inflows of sixty-nine developing countries by regression framework and found the importance of FDI as a means of transferring technology that contributes more to growth than domestic investment (Blanchard, 2017).

In 2010, Asia and Latin America accounted for 91 percent of China's non-financial outward FDI. In Asia, Hong Kong attracted 88 percent of China's non-financial outward FDI in the region, indicating Hong Kong's very important role as a bridge for Chinese firms investing abroad (Bank, 2014). In Latin America, British Virgin Island and Cayman Island attracted 96 percent of China's non-financial OFDI in the region. Together, these three onshore and off shore financial centers accounted for 81.6 percent of China's non-financial OFDI stock globally,in2010.Asthese financial centers have a common characteristic, that is, a low-tax or tax-free business environment, they have become very attractive locations for many mainland Chinese firms to register in and subsequently 
invest back into China in order to obtain preferential treatment for inward FDI, in addition of unction gas bridges for investments abroad. This is known as "round tripping" the investments, and is still an important phenomenon regarding Chinese outward FDI. I will look closer at the term round tripping in the next section.

\section{Research Methodology}

\subsection{Regression model}

Consistent with the theory above my main specification includes GDP, EXPORT,

CAPITAL, INVEST, MENT, TRADE, INFLATION, more precisely, the main estimated equation of determinants China's FDI in Bangladesh.

$\mathrm{FDI}=\mathrm{GDP}+\mathrm{EXPORT}+\mathrm{CAPITAL}$ INVESTMENT + TRADE + INFLATION

FDI: Foreign direct investment (FDI) is an investment made by a company or individual in one country in business interests in another country. Generally, FDI takes places when an investor establishes foreign business operations or acquires foreign business assets, including establishing ownership or controlling interest in a foreign company. Foreign direct investments are distinguished from portfolio investments in which an investor merely purchases equities of foreign-based companies.

GDP: Gross domestic product (GDP) is the monetary value of all the finished goods and services produced with in a country's borders in a specific time period(Ahmed, 2001).Though GDP is usually calculated on an annual basis, it can be calculated on a quarterly basis as well (in the United States, for example, the government releases an annualized GDP estimate for each quarter and also for an entire year).

Export: There are many factors that can affect export. It is assumed that FDI Inflow is one of the prominent factors that influence the export. If the explanatory power of FDI Inflow, the independent variable is high over export, the dependent variable, the assumption will be proved.

Capital investment: Capital investment refers to funds invested in a firm or enterprise for the purpose of furthering its business objectives. Capital investment may also refer to a firm's acquisition of capital assets or fixed assets such as manufacturing plants and machinery that is expected to be productive over many years. Sources of capital investment are manifold and can include equity investors, banks, financial institutions, venture capital.

Trade: Trade is a basic economic concept involving the buying and selling of goods and services, with compensation paid by a buyer to a seller, or the exchange of goods or services between parties. The most common medium of exchange for these transactions is money, but trade may also be executed with the exchange of goods or services between both parties, referred to as a barter, or payment with virtual currency, the most popular of which is bitcoin. In financial markets, trading refers to the buying and selling of securities, 


\section{Determinants of China Foreign Direct Investment (FDI's) in Bangladesh from the}

Perspective of Economic Development

such as the purchase of stock on the floor of the New York Stock Exchange (NYSE).

INFLATION: Inflation is defined as a sustained increase in the general level of prices for goods and services in a county, and is measured as an annual percentage change. Under conditions of inflation, the prices of things rise over time. Put differently, as inflation rises, every dollar you own buys a smaller percentage of a good or service. When prices rise, and alternatively when the value of money falls you have inflation.

\subsection{Data collection}

The main source of data collection is through the secondary source. Data of major economic indicators of Bangladesh for 14 years (from 2003 to 2016) had been collected through various websites. Major part of which had been collected from statistical year book of Bangladesh, World Bank and FDI.

For the sample size, annual observations of major economic indicators of Bangladesh (GDP, EXPORT, CAPITAL INVESTMENT, TRADE, and INFLATION) for 14 years starting from 2003 to 2016 had been included in the sample size for running econometric and time series tests for accurate results.

The dependent variable in my analysis is the annual aggregate Chinese FDI in Bangladesh. I use data on Chinese FDI to Bangladesh for period 2003-2016 had been collected from statistical year book of China. This data is combined with data from the Bangladesh Bureau statistics. The selection of independent variable to a large extent mirrors and are common in the literature on determinants of Chinese foreign direct investment. The proxies used to for main Independent variables and the resource of data are presented in this table.

Table 1: Definition of variable

\begin{tabular}{lll}
\hline Variables & Proxy & Source \\
\hline 1.GDP & Bangladesh GDP & World development indicator \\
2.EXPORT & Bangladesh Export & Bangladesh bureau of statistics \\
3.Capital investment & Bangladesh Capital investment & Bangladesh bureau of statistics \\
4.Trade & Bangladesh trade & World bank database \\
5.Inflation & Bangladesh inflation & Bangladesh bureau of statistics \\
6.FDI & Chinese FDI & Statistical yearbook of China \\
\hline
\end{tabular}

Analytical method: According to Don Ethridge (2004-24P) Analytical research, tends to be based largely on making sense of the mass of information on the subject. Consequently, this approach gave us a systematic meaning in interpreting data collected. Indeed, this method helped us establish why the save rate decreases and what procedure to follow in order to overcome this issue.

\section{Data Analysis and Interpretation Result}


Dulal Roy

\subsection{Variables}

The current study is analyzing the relationship among foreign direct investment, Trade and Economic growth. In this study, I used six variables, Foreign Direct Investment (FDI), GDP. Exports, Capital investment, trade and Inflation for Bangladesh. All series of data are based on the annual data and sample period of annual observation is from 2003 to 2016. I got this data from various economics survey of Bangladesh.

Model: FDI $=$ GDP+EXPORT+CAPITAL INVESTMENT+TRADE+ INFLATION

\subsection{Multi-collinearity Test}

We examine the multicollinearity by conducting VIF test. According to relevant theories, multicollinearity is presence if value of VIF is greater than 10. The VIF values with all independent variables are shown in following table. We can see the variable of Export should be removed in order to decrease the possibility of multi-collinearity.

Table 2: Multi-collinearity test

\begin{tabular}{ccc}
\hline \multirow{2}{*}{ Model } & \multicolumn{2}{c}{ Statistics } \\
\cline { 2 - 3 } & $\mathbf{1 / V I F}$ & VIF \\
\hline Constant & .014 & 71.759 \\
GDP & .009 & 111.164 \\
EXPORT & .038 & 26.158 \\
CINVEST & .110 & 9.088 \\
TRADE & .479 & 2.089 \\
INFLATION & & \\
\hline
\end{tabular}

After remove the variable of Export, the renewed VIF values are shown below. It demonstrates that the variable of CINVEST should be dropped.

Table 3: Multi-collinearity test

\begin{tabular}{ccc}
\hline Model & \multicolumn{2}{c}{ Statistics } \\
\cline { 2 - 3 } & $\mathbf{1 / V I F}$ & VIF \\
\hline 1Constant & .079 & 12.633 \\
GDP & .042 & 23.816 \\
CINVEST & .141 & 7.083 \\
TRADE & .645 & 1.552 \\
INFLATION & & \\
\hline
\end{tabular}

After dropping the CINVEST, the VIF results are shown below. It reveals that the multicollinearity is absence. Therefore, the final independent variables we are going to 
Determinants of China Foreign Direct Investment (FDI's) in Bangladesh from the Perspective of Economic Development

use are GDP, TRADE, and INFLATION.

Table 4: Multi-collinearity test

\begin{tabular}{ccc}
\hline \multirow{2}{*}{ Model } & \multicolumn{2}{c}{ Statistics } \\
\cline { 2 - 3 } & 1/VIF & VIF \\
\hline 1Constant & & \\
GDP & .416 & 2.405 \\
TRADE & .318 & 3.143 \\
INFLATION & .666 & 1.501 \\
\hline
\end{tabular}

\subsection{Heteroskedasticity test}

After dropping variable of EXPORT and CINVEST, we examine the presence of heteroskedasticity. The route is regression estimation/ residual diagnostic/ heteroskedasticity test. By selecting the method of Breusch-Pagan test, the probability of heteroskedasticity is reported. If the prob. Value is lower than 0.05 , it proves the presence of heteroskedasticity. For our data, the result of Breusch-Pagan-Godfrey shows that the prob. Value is greater than 0.05 , demonstrating that the heteroskedasticity is absence.

Table 5: Heteroskedasticity test: breusch-pagan-godfrey

\begin{tabular}{|c|c|c|}
\hline F-statistic & 0.729984Prob. F (3,10) & 0.5572 \\
\hline Obs*R-squared & 2.515131Prob. Chi-Square (3) & 0.4726 \\
\hline Scaled explained SS & 1.021802Prob. Chi-Square (3) & 0.796 \\
\hline
\end{tabular}

\subsection{Co-integration test}

Through Johansen System Cointegration test we can find out how many variables have linear relationships. Normally, the result involved the largest number of variables will be accepted if there are more than one results are of significant. For the testing result, it shown that the None* result includes the most variables in both the two optional testing methods. It means that there are linear relationships between FDI, GDP, TRADE, and INFLATION.

Table 6: Unrestricted cointegration rank test

\begin{tabular}{ccccc}
\hline $\begin{array}{c}\text { Hypothesized } \\
\text { No. of CE(s) }\end{array}$ & Eigenvalue & $\begin{array}{c}\text { Trace } \\
\text { Statistic }\end{array}$ & $\begin{array}{c}\mathbf{0 . 0 5} \\
\text { Critical Value }\end{array}$ & Prob.** \\
\hline None $*$ & 0.946035 & 66.50277 & 47.85613 & 0.0004 \\
At most 1 & 0.712675 & 28.55040 & 29.79707 & 0.0691 \\
At most 2 & 0.610293 & 12.33757 & 15.49471 & 0.1415 \\
\hline
\end{tabular}


Dulal Roy

\begin{tabular}{lllll}
\hline At most 3 & 0.006662 & 0.086896 & 3.841466 & 0.7682 \\
\hline
\end{tabular}

By formulating linear regression model based on these four variables, we obtain the following regression result. The prob. Values for each independent variable show that the GDP and TRADE impacts the inflow of FDI in Bangladesh significantly, while the INFLATION does not play significant role on FDI. The model fitness (R square) is 0.8179 , demonstrating that the variable of GDP and TRADE can explain the change of FDI by 81.79 percentage. The fitness is good.

Log FDI $=-1.411+0.711 \log$ GDP+1.489LogTRA-0.319LogINFLATION

$(0.3224)(0.0283)(0.0457)(0.2742)$

Table 7: Regression result

\begin{tabular}{ccccc}
\hline Variable & Coefficient & Std. Error & t-Statistic & Prob. \\
\hline C & -1.411459 & 1.355823 & -1.041035 & 0.3224 \\
$\log (\mathrm{GDP})$ & 0.711087 & 0.277553 & 2.561989 & 0.0283 \\
$\log (\mathrm{TRA})$ & 1.488618 & 0.652487 & 2.281453 & 0.0457 \\
$\log (\mathrm{INF})$ & -0.319255 & 0.275957 & -1.156902 & 0.2742 \\
\hline R-squared & 0.859937 & Mean dependent var & 6.700454 \\
Adjusted & 0.817918 & S.D. dependent var & 0.561385 \\
R-squared & & & \\
$\quad$ S.E. of & 0.239549 & Akaike info criterion & 0.214839 \\
regression & & & \\
Sum squared & 0.573837 & Schwarz criterion & 0.397426 \\
$\quad$ resid & 2.496129 & Hannan-Quinn criter. & 0.197937 \\
$\log$ likelihood & 20.46545 & Durbin-Watson stat & 2.206357 \\
F-statistic & 0.000137 & & \\
Prob(F-statistic) & & &
\end{tabular}

\section{Results and discussion}

The main finding in this time series analysis is that the interaction term between GDP and Export, trade, FDI and inflation are significant and positive. This result contracts previous research, as previous research has found Chinese FDI to be attract to countries' that have poor institution and may suggest that the Chinese investment in Bangladesh have involves in recent year. Through Johansen System Co -integration test we can find out how many variables have linear relationships. Normally, the result involved the largest number of variables will be accepted if there are more than one results are of significant. For the testing result, it shown that the none* result includes the most variables in both the two optional testing methods. It means that there are linear 
Determinants of China Foreign Direct Investment (FDI's) in Bangladesh from the Perspective of Economic Development

relationships between FDI, GDP, TRADE, and INFLATION.

Results show that the first difference values of variables are all stationary at the significance level of 0.1. Although not as ideal as significance level of 0.05 , it is still accepted if the Prob. Value is smaller than 0.1. As a result, the variable and data of FDI, GDP, EXPORT, TRADE and INFLATION could be used to do further regression estimation.

Through Johansen System Co -integration test we can find out how many variables have linear relationships. Normally, the result involved the largest number of variables will be accepted if there are more than one results are of significant. For the testing result, it shown that the none* result includes the most variables in both the two optional testing methods. It means that there are linear relationships between FDI, GDP, TRADE, and INFLATION.

By formulation linear regression model based on these four variables, we obtain the following regression result. The prob. Values for each independent variable show that the GDP and TRADE impacts the inflow of FDI in Bangladesh significantly, while the INFLATION does not play significant role on FDI. The model fitness ( $\mathrm{R}$ square) is 0.8179 , demonstrating that the variable of GDP and TRADE can explain the change of FDI by 81.79 percentage. The fitness is good.

This thesis is an attempt to identify and point up the main determinants of China's FDI in Bangladesh perspective economic development. The main object targets are to achieve on the long term for becoming emerging economies. In this respect, knowing macroeconomic aggregate on which they must rely on to unleash their potential and gain a sustainable economic growth is essential. Six variables were selected from the literature review.

Final Bangladesh should have strong institution and credible to unsure the political and macroeconomic stability growth. Bangladesh must invest more human capital, especially in technical and scientific field. Export must be diversified and not only export raw materials. Bangladesh should focus on manufactures goods having an added value which could bring job creation and generate economic development necessary to reach the stage of emerging economies.

\section{REFERENCES}

1. N.Ahmed, Trade liberalization in Bangladesh: An investigation into trends. University Press Limited, (2001).

2. S.Ahmed, M.Hasanuzzaman, M.S.I.Chowdhury, M.E.Shaikh and M.S.Munir, A survey on the factors affecting employee turnover in the readymade garments of Bangladesh, Global Journal of Research in Engineering (2018). 
3. B.Bank, Foreign direct investment (FDI) in Bangladesh, Survey Report (2014).

4. E.J.Blanchard and W.W.Olney, Globalization and human capital investment: Export composition drives educational attainment, Journal of International Economics, 106 (2017) 165-183.

5. H.Feldmann, Economic freedom and human capital investment, Journal of Institutional Economics, 13(2) (2017) 421-445.

6. M.Islam and D.C.Pattak, Impact of macro environmental factors on garments industry that drives export in Bangladesh, Studies in Business and Economics, 12(2) (2017) 100-111.

7. R.Islam, Factors Affecting Per Capita GDP in Bangladesh: An Econometric Analysis, (2017).

8. B.O.Kolawole and S.A.Odubunmi, Government capital expenditure, foreign direct investment, and economic growth relationship in Nigeria, Mediterranean Journal of Social Sciences, 6(4) (2015) 444-444.

9. S.Kumar and S.Ahmed, Growth and Pattern of Intra-Industry Trade between India and Bangladesh: 1975-2010, The Journal of International Economic Policy, (2) (2014) 21

10. C.Long, J.Yang and J.Zhang, Institutional impact of foreign direct investment in China, World Development, 66 (2015) 31-48.

11. S.Mitra, Effect of Foreign Direct Investment on GDP, Export and Domestic Investment: Bangladesh Perspective. Journal of Innovation \& Development Strategy (JIDS), 9(2) (2015).

12. S.Raihan, S.R.Osmani and M.B.Khalily, Contribution of Microfinance to the Gross Domestic Product (GDP) of Bangladesh. Institute of Microfinance (Working Paper No. 44) (2015).

13. T.S.Roy, R.Chakraborty, M.N.Parvez, S.Biswas and S.Chakraborty, Development of sustainable gross national income from potato export in Bangladesh-A perspective review, Univers J Agric Res., 5(1) (2017) 46-51.

14. R.Sharmin and S.Khandaker, The Determinant of Foreign Direct Investments, Evidence from Bangladesh. Evidence from Bangladesh (2015). 